\title{
Development of Bone Morphogenetic Protein Receptors in the Nervous System and Possible Roles in Regulating trkC Expression
}

\author{
Damin Zhang, Mark F. Mehler, Qingbin Song, and John A. Kessler \\ Departments of Neurology and Neuroscience and the Rose F. Kennedy Center for Research in Mental Retardation and \\ Human Development, Albert Einstein College of Medicine, Bronx, New York 10461
}

\begin{abstract}
Characterization of bone morphogenetic protein receptor (BMPR) expression during development is necessary for understanding the role of these factors during neural maturation. In this study, in situ hybridization analyses demonstrate that BMPspecific type I (BMPR-IA and BMPR-IB) and type II (BMPR-II) receptor $m R N A s$ are expressed at significant levels in multiple regions of the CNS, cranial ganglia, and peripheral sensory and autonomic ganglia during the embryonic and neonatal periods. All three BMP receptor subunits are expressed within periventricular generative zones. BMPR-IA is more abundant than the other receptor subtypes, with widespread expression in the brain, cranial ganglia, and peripheral ganglia. By contrast, BMPR-IB mRNA displays significant expression within more restricted regions, including the anterior olfactory nuclei. BMPR-II mRNA exhibits peak expression within the cerebellar Purkinje cell layer and the hippocampus, as well as within
\end{abstract}

cranial ganglia. The distribution of BMP receptors within large neurons in adult dorsal root ganglia suggested a possible role in regulating expression of the neurotrophin receptor trkC. This hypothesis was tested in explant cultures of embryonic day 15 (E15) and postnatal day 1 (P1) sympathetic superior cervical ganglia (SCG). Treatment of the E15 or the P1 SCG with BMP-2 induced expression of trkC mRNA and responsiveness of sympathetic neurons to NT3 as measured by neurite outgrowth. The pattern of expression of BMP receptors in embryonic brain suggests several potentially novel areas for further developmental analysis and supports numerous recent studies that indicate that BMPs have a broad range of cellular functions during neural development and in adult life.

Key words: bone morphogenetic protein receptor; subventricular zone; cranial ganglia; dorsal root ganglia; gliogenesis; olfactory nuclei
The bone morphogenetic proteins (BMPs) are members of the transforming growth factor $\beta$ (TGF- $\beta$ ) superfamily (for review, see Kingsley, 1994; Hogan, 1996). They are involved in a number of cellular and molecular processes, including bone formation (Urist et al., 1979; Wozney et al., 1988), mesoderm induction (Dale et al., 1992), neurulation (Wilson and Hemmati-Brivanlou, 1995), dorsoventral patterning of the neural tube (Liem et al., 1995; Arkell and Beddington, 1997), apoptosis (Graham et al., 1994), neural differentiation (for review, see Mehler et al., 1997), and limb morphogenesis (Francis et al., 1994; Johnson et al., 1994; Kawakami et al., 1996). The BMPs are epidermal inducers that inhibit neurulation, and anterior neurulation is orchestrated by inhibition of BMP signaling (Wilson and Hemmati-Brivanlou, 1995; Tanabe and Jessell, 1996; Hemmati-Brivanlou and Melton, 1997). Within the neural tube they act as gradient morphogens to promote the differentiation of dorsal cell types and participate through cooperative signaling in specification of intermediate dorsoventral cell types (Hogan, 1996; Holley et al., 1996; Piccolo et al., 1996; Tanabe and Jessell, 1996; Zimmerman et al., 1996). They also regulate segmentation of rhombomeres by inducing

\footnotetext{
Received Feb. 2, 1998; accepted Feb. 18, 1998.

This work was supported by an Irma T. Hirschl Career Scientist Award (M.F.M.) and grants from the Muscular Dystrophy Association (M.F.M.) and the National Institutes of Health (NS35320 to M.F.M. and NS20013 and NS20778 to J.A.K.). We are grateful to Drs. Anthony Celeste and John Wozney of Genetics Institute for providing molecular probes for BMP receptor subunits and Dr. Kohei Miyazono of the Cancer Institute (Tokyo, Japan) for providing affinity-purified antibodies to BMP type I and type II receptor subunits. We thank Ms. Antoinette Barnecott for her expert assistance in the preparation of this manuscript.

Correspondence should be addressed to John A. Kessler, Albert Einstein College of Medicine, 1300 Morris Park Avenue, Bronx, New York 10461.

Copyright (C) 1998 Society for Neuroscience $\quad 0270-6474 / 98 / 183314-13 \$ 05.00 / 0$
}

apoptosis of selected neural crest-associated cellular populations (Graham et al., 1994, 1996). In the peripheral nervous system (PNS) they act as instructive signals for neuronal lineage commitment and regulate subsequent neuronal differentiation (Varley et al., 1995; Shah et al., 1996; Reissmann et al., 1996; Varley and Maxwell, 1996), whereas in the brain they promote astroglial lineage commitment (Gross et al., 1996). They also regulate neuronal survival and differentiation in both the brain and the PNS (Lein et al., 1995, 1996; Mehler and Kessler, 1995).

BMPs exert their biological effects by binding to type I (BMPR-IA and BMPR-IB) and type II (BMPR-II) receptor subunits (Koenig et al., 1994; ten Dijke et al., 1994a; Nohno et al., 1995; Liu et al., 1995; Rosenzweig et al., 1995) that are organized with minor modifications of the prototypical TGF- $\beta$ subclass receptors (Massague, 1996). In addition, different BMP subgroups may also signal through a second class of receptors that are also activin receptors (ActRs). Here we describe the regional and cellular localization of the three BMP-specific receptor subunit mRNAs in the developing and adult mouse nervous systems and the corresponding expression of two of the BMP receptor subunit proteins. BMPR-IA mRNA exhibits the broadest range and highest levels of expression in prenatal, postnatal, and adult mouse brain, cranial ganglia, and peripheral sensory and sympathetic ganglia. In addition, expression of BMPR-IB and BMPR-II mRNAs is prominent during the early postnatal period in several regions of mouse brain and in cranial ganglia. The pattern of expression suggested several potential functions for the BMPs, including a possible role in regulating expression of the neurotrophin receptor trkC. As predicted, BMP-2 treatment of explants of the superior cervical ganglion was found to induce trkC 
expression as well as neurotrophin 3 (NT3) responsiveness. More generally, characterization of the development and distribution of BMP receptor transcripts in developing brain and peripheral ganglia provide the basis for predicting other potential roles for the ligands in neural development.

\section{MATERIALS AND METHODS}

Tissue preparation. CD1 mouse embryos were fixed in $4 \%$ paraformaldehyde in PBS at $4^{\circ} \mathrm{C}$ overnight. After fixation, tissue was exposed to $30 \%$ sucrose overnight at $4^{\circ} \mathrm{C}$ and then frozen for cryostat sectioning. The postnatal mouse brain was directly chilled in liquid nitrogen for cryostat sectioning without prefixation. Sections $(12-16 \mu \mathrm{m})$ were cut, post-fixed in $4 \%$ paraformaldehyde in PBS for $15 \mathrm{~min}$, rinsed twice in PBS, dehydrated through a graded series of ethanol washes, and stored at $-70^{\circ} \mathrm{C}$ before use.

Preparation of $c R N A$ probes. The probe used to survey the expression of BMPR-IA was a 262 bp fragment corresponding to mouse BMPR-IA cDNA sequence, 110-372 bp (Dewulf et al., 1995). The BMPR-IB riboprobe was transcribed from a $486 \mathrm{bp}$ fragment corresponding to mouse BMPR-IB cDNA sequence, 359-845 bp (ten Dijke et al., 1994b). The BMPR-II riboprobe was transcribed from a 348 bp fragment corresponding to human BMPR-II cDNA sequence, 484-832 bp (Nohno et al., 1995). Reverse transcription-PCR was subsequently performed. The fragments were inserted into the corresponding plasmids: pGEM$78 \mathrm{f}(+/-)$ plasmid was used for type I receptors, and AT plasmid was used for the type II receptor. The trkC probe was generated from a 676 bp fragment that includes part of the kinase domain. Antisense and sense riboprobes were transcribed with a Promega (Madison, WI) kit following the manufacturer's instructions.

In situ hybridization. In situ hybridization was performed by post-fixing sections in $0.1 \mathrm{~m}$ sodium phosphate-buffered $4 \%$ paraformaldehyde, $\mathrm{pH}$ 7.4, for $30 \mathrm{~min}$, rinsing in PBS for $1 \mathrm{~min}$, rinsing in $2 \times \mathrm{SSC}$ for $1 \mathrm{~min}$, acetylation with $0.5 \%$ acetic anhydride in $0.1 \mathrm{M}$ triethanolamine, $\mathrm{pH} 8.0$, for $10 \mathrm{~min}$, rinsing again in $2 \times \mathrm{SSC}$ and then in PBS, and finally dehydrating in a graded series of ethanol washes. The slides were prehybridized in $2 \times \mathrm{SSC}$ and $50 \%$ formamide at $50^{\circ} \mathrm{C}$ for $2 \mathrm{hr}$ and hybridized using hybridization buffer containing $2 \times 10^{4} \mathrm{cpm} / \mu \mathrm{l}$ cRNA probe (hybridization buffer, $0.75 \mathrm{M} \mathrm{NaCl}, 50 \%$ formamide, $1 \times$ Denhardt's solution, $10 \%$ dextran sulfate, $30 \mathrm{~mm}$ DTT, $10 \mathrm{~mm}$ Tris-HCl, pH 7.5, 1 mm EDTA, $100 \mathrm{ug} / \mathrm{ml}$ salmon sperm DNA, and $0.5 \mathrm{mg} / \mathrm{ml}$ yeast tRNA) at $50^{\circ} \mathrm{C}$ for $16 \mathrm{hr}$. Slides were then washed twice in $2 \times \mathrm{SSC}$ for 2 min; in $2 \times \mathrm{SSC}, 50 \%$ formamide, and $0.1 \% \beta$-mercaptoethanol (BME) at $50^{\circ} \mathrm{C}$ for $1 \mathrm{hr}$; in $20 \mu \mathrm{g} / \mathrm{ml} \mathrm{RNase} \mathrm{A}$ at $37^{\circ} \mathrm{C}$ for $30 \mathrm{~min}$; in $0.5 \mathrm{M} \mathrm{NaCl}$ and $10 \mathrm{~mm}$ Tris- $\mathrm{HCl}, \mathrm{pH} 8.0$; in $2 \times \mathrm{SSC}, 50 \%$ formamide, and $0.1 \%$ $\mathrm{BME}$ at $58^{\circ} \mathrm{C}$ for $30 \mathrm{~min}$; and in $0.1 \times \mathrm{SSC}$ and $0.1 \% \mathrm{BME}$ at $63^{\circ} \mathrm{C}$ for 30 min, with final dehydration. The sections were then exposed to $\mathrm{x}$-ray film for 4 or $5 \mathrm{~d}$ to obtain autoradiograms, dipped in emulsion, and exposed for 6-8 weeks, with cresyl violet used as counterstain. In cases in which in situ hybridization was combined with immunocytochemistry, slides were processed for immunocytochemical analysis before radioautographic detection of ${ }^{35} \mathrm{~S}$. Use of the sense riboprobe confirmed the specificity of labeling.

Ribonuclease protection assay. Antisense riboprobes for BMP-IA, BMP-IB, BMPR-II, and trkC were generated in $25 \mu \mathrm{l}$ of buffer containing $200 \mathrm{~mm}$ Tris-Cl, $\mathrm{pH} 7.5,30 \mathrm{~mm} \mathrm{MgCl}, 10 \mathrm{~mm}$ spermidine, $50 \mathrm{~mm}$ $\mathrm{NaCl}, 0.4 \mathrm{~mm}$ ATP, $0.4 \mathrm{~mm}$ GTP, $0.4 \mathrm{~mm}$ UTP, $10 \mathrm{ml}$ of $\left[\alpha^{-32} \mathrm{P}\right] \mathrm{CTP}, 800$ $\mathrm{Ci} / \mathrm{mmol}, 20 \mathrm{~mm}$ DTT, $20 \mathrm{U}$ of ribonuclease inhibitor, $0.5 \mathrm{mg}$ of template, and $20 \mathrm{U}$ of T7 or SP6 RNA polymerase. The mixture was incubated at $40^{\circ} \mathrm{C}$ for SP6 or at $37^{\circ} \mathrm{C}$ for $\mathrm{T} 7(60 \mathrm{~min})$. Probes were purified using gel filtration. mRNA from mouse brains $(10 \mu \mathrm{g})$ was hybridized with $5 \times 10^{5} \mathrm{cpm}$ of BMPR RNA probes at $60^{\circ} \mathrm{C}$ overnight. The mixture was digested with $40 \mu \mathrm{g} / \mathrm{ml}$ ribonuclease A and $2 \mu \mathrm{g} / \mathrm{ml}$ ribonuclease T1. Hybridized RNAs were run on $5 \%$ polyacrylamide gels and visualized by autoradiography. mRNA from cultured ganglia $(5 \mu \mathrm{g})$ for analysis of trkC and actin was treated similarly, except that the concentration of ribonuclease $\mathrm{T} 1$ was $2.5 \mu \mathrm{g} / \mathrm{ml}$.

Immunoblotting. Cellular suspensions of mouse brains (Charles River Laboratories, Wilmington, MA) in lysis buffer (1\% Triton X-100, $0.1 \%$ SDS, $1 \%$ sodium deoxycholate, $1 \mathrm{~mm}$ iodoacetamide, $0.2 \mathrm{mg} / \mathrm{ml}$ aprotinin, $1 \mathrm{~mm}$ phenylmethylsulfonyl fluoride, $0.01 \mathrm{~m}$ Tris-Cl, $\mathrm{pH} 8.0,0.14 \mathrm{M}$ $\mathrm{NaCl}$, and $0.025 \% \mathrm{NaN}_{3}$ ) were shaken for $1 \mathrm{hr}$ at $4^{\circ} \mathrm{C}$. Insoluble debris was removed by centrifugation at $10,000 \mathrm{rpm}$ for $10 \mathrm{~min}$. Protein mixtures $(\sim 5 \mu \mathrm{g})$ were loaded on $8 \%$ SDS-PAGE gels and transferred to nitrocellulose membranes. Membranes were probed with affinity-purified

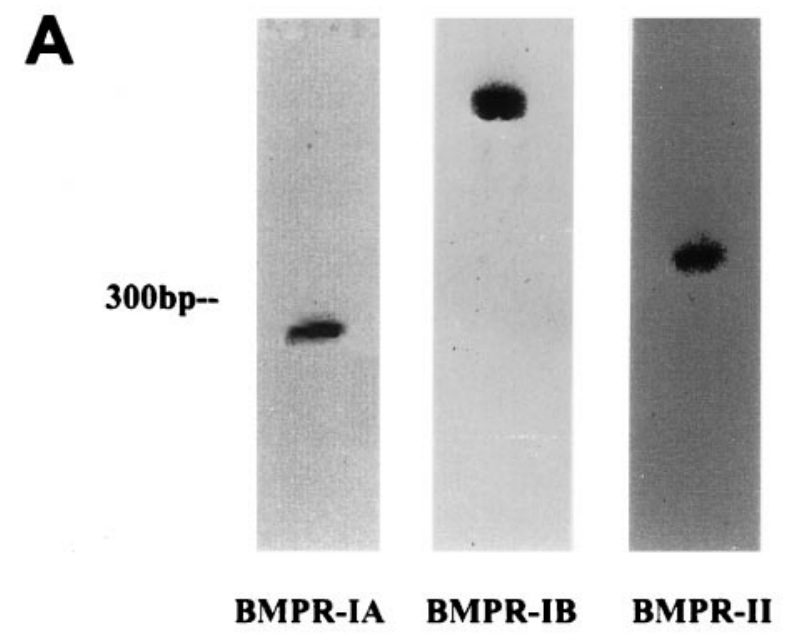

B

BMPR-1A

E9 E13 E16 PN1 PN7 PN12 Ad

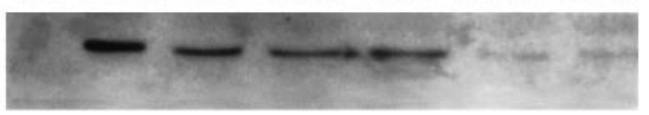

\section{BMPR-II}

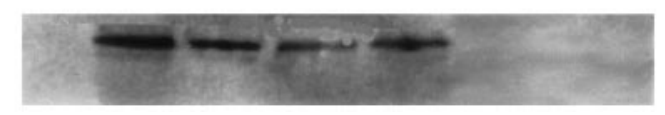

Figure 1. A, Expression of BMPR-IA, BMPR-IB, and BMPR-II mRNAs in neonatal mouse whole brain samples as detected by RNase protection assays. $B$, Western blot analyses of BMPR-IA and BMPR-II proteins in embryonic $(E 9, E 13, E 16)$, postnatal $(P 1, P 7, P 12)$, and adult $(A d)$ whole brains.

BMPR-IA, BMPR-IB, and BMPR-II antibodies (a generous gift from Dr. K. Miyazono, The Cancer Institute, Tokyo, Japan). Blots were developed using the ECL reagent (Amersham, Arlington Heights, IL).

Immunocytochemistry. After the slides were processed through in situ hybridization protocols, they were immunocytochemically stained using an avidin-biotin-peroxidase technique (Vectastain Elite mouse IgG ABC kit; Vector Laboratories, Burlingame, CA). Neurons were identified by the presence of signal to anti-NF68 antibodies (1:200 dilution; Sigma, St. Louis, MO). Oligodendrocytes were identified with antiCNPase antibodies (1:1000 dilution; Sternberger Monoclonals Inc.). Astrocytes were identified with anti-glial fibrillary acidic protein (GFAP) antibodies (1:400 dilution; Sigma).

Culture of sympathetic ganglia. Superior cervical ganglia were dissected from E15 and neonatal mice and were cultured as described previously (Kessler et al., 1981) on a collagen substratum in serum-free medium (Neurobasal Plus B27 supplements; Life Technologies, Gaithersburg, $\mathrm{MD})$. The E15 ganglia were cultured in the absence of NGF, whereas neonatal ganglia were all treated with NGF $(10 \mathrm{ng} / \mathrm{ml})$.

\section{RESULTS}

To determine the spatial and temporal patterns of expression of BMP receptors, mouse brains were processed for in situ hybridization using ${ }^{35} \mathrm{~S}$-labeled BMP receptor riboprobes. The specificity of the hybridization signals was determined using two separate techniques. First, ${ }^{35} \mathrm{~S}$-labeled sense riboprobes produced only background levels of hybridization (see Fig. 7g,h). Second, in RNase protection assays each cRNA probe hybridized specifically with a single poly $\left(\mathrm{A}^{+}\right)$RNA transcript isolated from mouse brain 

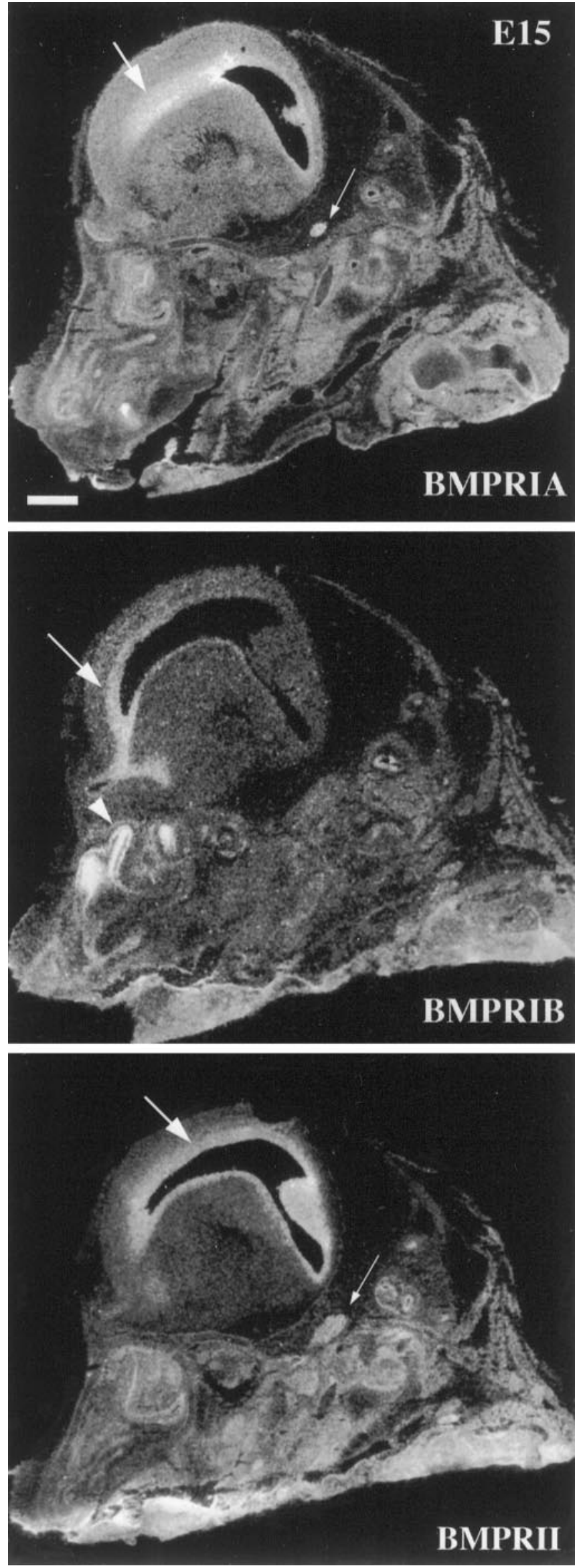

(Fig. 1A). Furthermore, immunoblotting with affinity-purified polyclonal antibodies to the BMP receptor subunits demonstrated developmental regulation of protein expression (Fig. 1B) that correlated with the results of the in situ studies.

Western blot analysis of BMPR-IA in whole brain from embryonic day 9 (E9) to adult revealed an absence of detectable expression at embryonic day 9, peak protein levels from embryonic day 13 to postnatal day 7 (P7), and reduced expression at P12 and in the adult (Fig. 1B). A similar pattern of expression was observed for the BMPR-II protein, except that abundance at P12 and in adult brain was much lower (Fig. $1 B$ ). Western blot analysis of BMPR-1B expression revealed multiple bands, precluding detailed developmental analysis (data not shown).

Differential expression of BMP-IA, BMPR-IB, and BMPR-II mRNAs in the developing nervous system

All three receptor subunits are expressed at E12, and the patterns of expression do not change substantially between E12 and E15. During this period, BMPR-IA mRNA is most abundantly expressed in the periventricular ventricular zone (VZ) and in the trigeminal ganglion (Fig. 2), whereas BMPR-IB mRNA is expressed within the anterior portion of the periventricular $\mathrm{VZ}$ (e.g., olfactory neuroepithelium and rhinencephalic neuroepithelium) and the olfactory primordia (Fig. 2). By contrast, BMPR-II mRNA at these early developmental stages is expressed within the entire extent of the VZ (Fig. 2). These results suggest that all three BMP receptor subunits may be involved in neural development at early embryonic stages.

At E16, BMPR-IA mRNA is most intensively expressed by cranial and peripheral ganglia, including the trigeminal ganglion, nodose ganglion, sympathetic ganglia, and dorsal root ganglia (DRG) (Figs. 3, 4). In brain, BMPR-IA is expressed within multiple structures, including the striatal neuroepithelium, the mitral cell layer, and the facial nuclei. The thalamus exhibits less abundant expression of BMPR-IA mRNA, and there are multiple other areas of low-level expression. By contrast to the wide expression of BMPR-IA, BMPR-IB mRNA at this stage is limited to the frontal region of the neuroepithelium and the olfactory epithelium, analogous to the pattern at E12 and E15 (Fig. 3). In the PNS, intensive labeling is seen within the nodose ganglion (data not shown) with persistence through E19. However, BMPR-IB is not detectable in trigeminal ganglion or DRG at these stages. BMPR-II mRNA is most abundant within the neuroepithelium surrounding the ventricle at E16 (Fig. 3). The mRNA is also expressed in the trigeminal and nodose ganglia (data not shown).

The intensive expression of BMPR-IA mRNA in DRG persists from E15 through later stages of development and into the adult (Fig. 4). In early embryos (E15), the mRNA is expressed in a homogeneous pattern throughout the DRG. By contrast, in later developmental stages and in the adult BMPR-IA mRNA expression is restricted to a subpopulation of larger, peripherally located neurons (Fig. 4). In the sympathetic superior cervical ganglion,

Figure 2. Expression of BMP receptor subunit mRNAs as detected by in situ hybridization and radioautography in sagittal sections of E15 mouse head. BMPR-IA mRNA is expressed by the VZ (arrow) and the trigeminal ganglion (small arrow) in the nervous system. The expression of BMPR-IB mRNA is restricted to the frontal region of the VZ (arrow) and the olfactory epithelium (arrowhead). BMPR-II mRNA is also expressed in the VZ (arrow) and the trigeminal ganglion (small arrow). Scale bar, $1 \mathrm{~mm}$. 
however, there is a homogeneous pattern of expression throughout development and into the adult (see Fig. 11D).

At E17-E18, BMPR-IA mRNA expression increases in the thalamus (Fig. 5). The mRNA is also found in hippocampus, periventricular subventricular zone (SVZ), superficial regions of the cortical plate, and the mitral cell layer. By contrast, BMPR-IB and BMPR-II are largely limited to the SVZ in brain at E17-E19 (data not shown). In addition, at E19, BMPR-IB mRNA is intensively expressed on the anterior olfactory nuclei (data not shown).

At P2, BMPR-IA mRNA is intensively expressed within the SVZ, frontal neocortex, striatum, piriform cortex, and taeniatecta (data not shown). By contrast, BMPR-IB mRNA is intensively expressed only in the anterior olfactory nuclei (Fig. 6) and in the SVZ (data not shown). The abundant expression of BMPR-IB mRNA in the olfactory epithelium correlates well with the early onset and persistent expression of BMPR-IB mRNA in anterior olfactory nuclei, suggesting that BMP-IB-mediated signaling may play an important role on the development and functioning of the olfactory system. BMPR-II mRNA is intensively expressed within the periventricular region (Fig. 6).

During P0-P14, BMPR-IA mRNA is broadly expressed in the mouse brain. In the neocortex, the most prominent expression is in the supragranular portion of the cortical plate. Expression within the thalamus at P4 is uniform (Fig. 7a), with no preferential labeling within specific thalamic nuclei; more specific labeling of thalamic nuclei begins at P6. BMPR-IA mRNA labeling is weak in the Purkinje cell layer of the cerebellum during the neonatal period (Fig. 7a). Intense and specific expression is evident over the ependymal layer of the SVZ (Fig. 7a); such ependymal expression is not found in either P14 or the adult brain (Figs. $7 b, 8)$. Although the dentate gyrus is not labeled, the other regions of the hippocampus display intensive labeling that persists at later developmental stages. Several other regional structures also exhibit patterns of BMPR-IA mRNA expression similar to those seen in P14 and adult brains. For instance, the pontine gray nuclei and the superior and inferior olivary nuclei express significant levels of BMPR-IA mRNA. The mitral cell layer of the olfactory bulb also displays intensive expression of BMPR-IA mRNA as seen in P14 and adult brain. By P14, the pattern of BMPR-IA expression is very similar to the one seen in adult brain, although labeling appears more diffuse. Strong expression is seen within the hippocampus, neocortex, mitral cell layer of the olfactory bulb, cerebellar Purkinje cell layer, and in nuclei of the thalamus and brainstem (Fig. 7b). In the neocortex, the labeling is differentially distributed over the various cell layers; the most intense labeling is seen over layers III, IV, and V, similar to the overall pattern seen in the adult cortex (Fig. 7b). BMPR-IA mRNA is also expressed within specific nuclei in the thalamus, such as the anterior dorsal, reticular, and ventral posterior thalamic nuclei. Unlike the adult brain, the choroid plexus of P14 mouse brain does not express BMPR-IA mRNA.

The expression of BMPR-IB mRNA within the anterior olfactory nuclei $(\mathrm{AON})$ persists from the neonatal period to the adult (Figs. $7 c, d, 8)$. However, the intensity of expression in the AON changes during development, with maximal expression at P14. These experimental observations suggest that BMPR-IB signaling may play a particularly prominent role in the maturation of neurons in the anterior olfactory nuclei. Furthermore, during the neonatal period, BMPR-IB mRNA is also discretely expressed in the ependymal layer of the SVZ (Fig. 7c).

At $\mathrm{P} 4$ and also at earlier stages, intense BMPR-II expression is
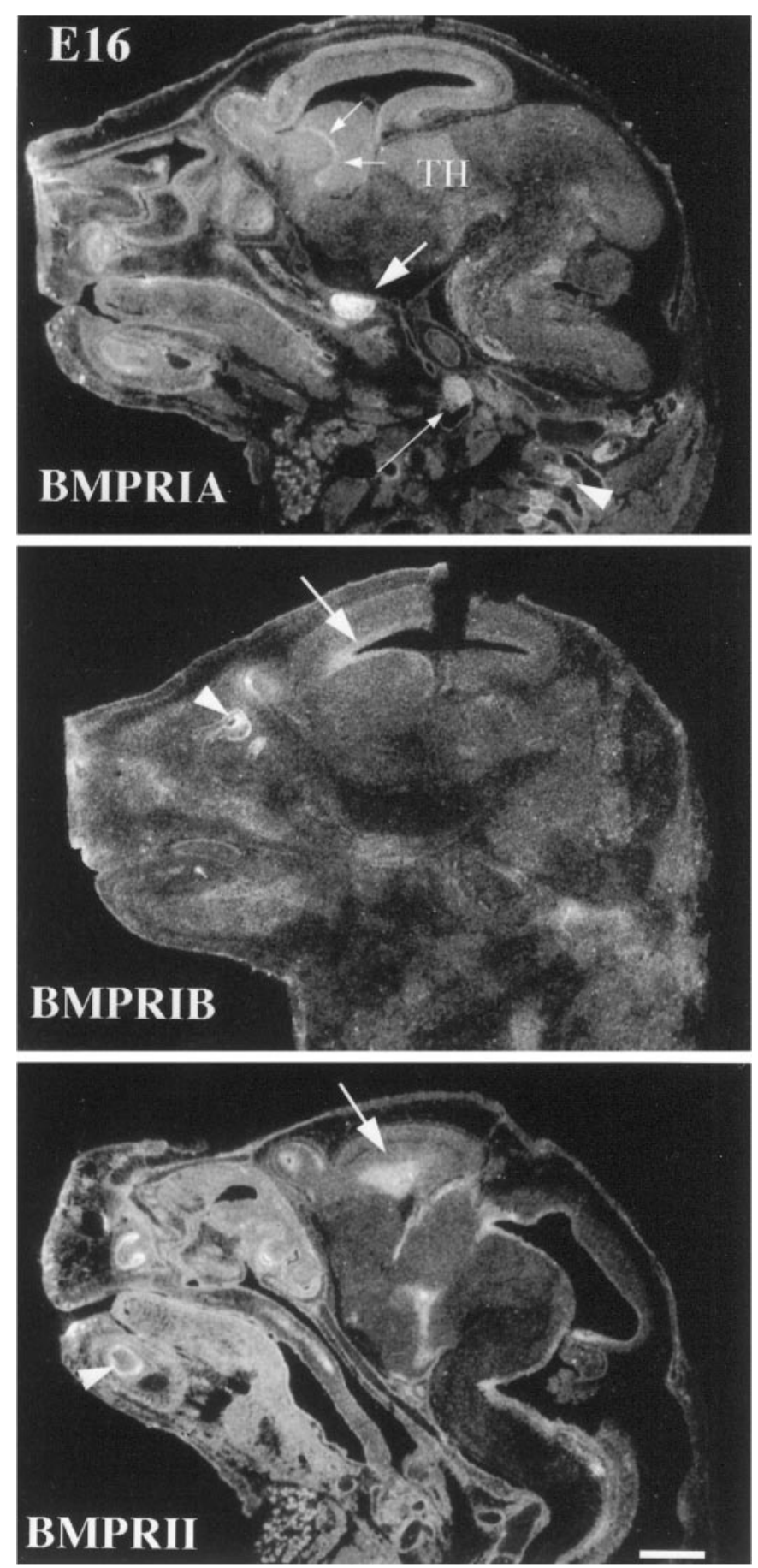

Figure 3. Expression of BMP receptor subunit mRNAs in the E16 mouse head. BMPR-IA mRNA is expressed at high levels in the trigeminal ganglion (arrow), nodose ganglion (small arrow), and DRG (arrow$h e a d$ ). It is also expressed by the striatum and the contiguous periventricular generative zone (small arrows). Relatively weak and diffuse expression is found in the thalamus $(T H)$. Expression of BMPR-IB mRNA is limited to the frontal region of the periventricular generative zone (arrow) and to the olfactory epithelium (arrowhead). BMPR-II mRNA is also expressed by the periventricular generative zone (arrow). Scale bar, $1 \mathrm{~mm}$.

found over the ependymal layer of the SVZ (Fig. 7e). The primordia of the cerebellar Purkinje cell layer and the facial nuclei in the brainstem also express BMPR-II at P0-P4. In the hippocampus, high levels of BMPR-II mRNA are found at P14; by 

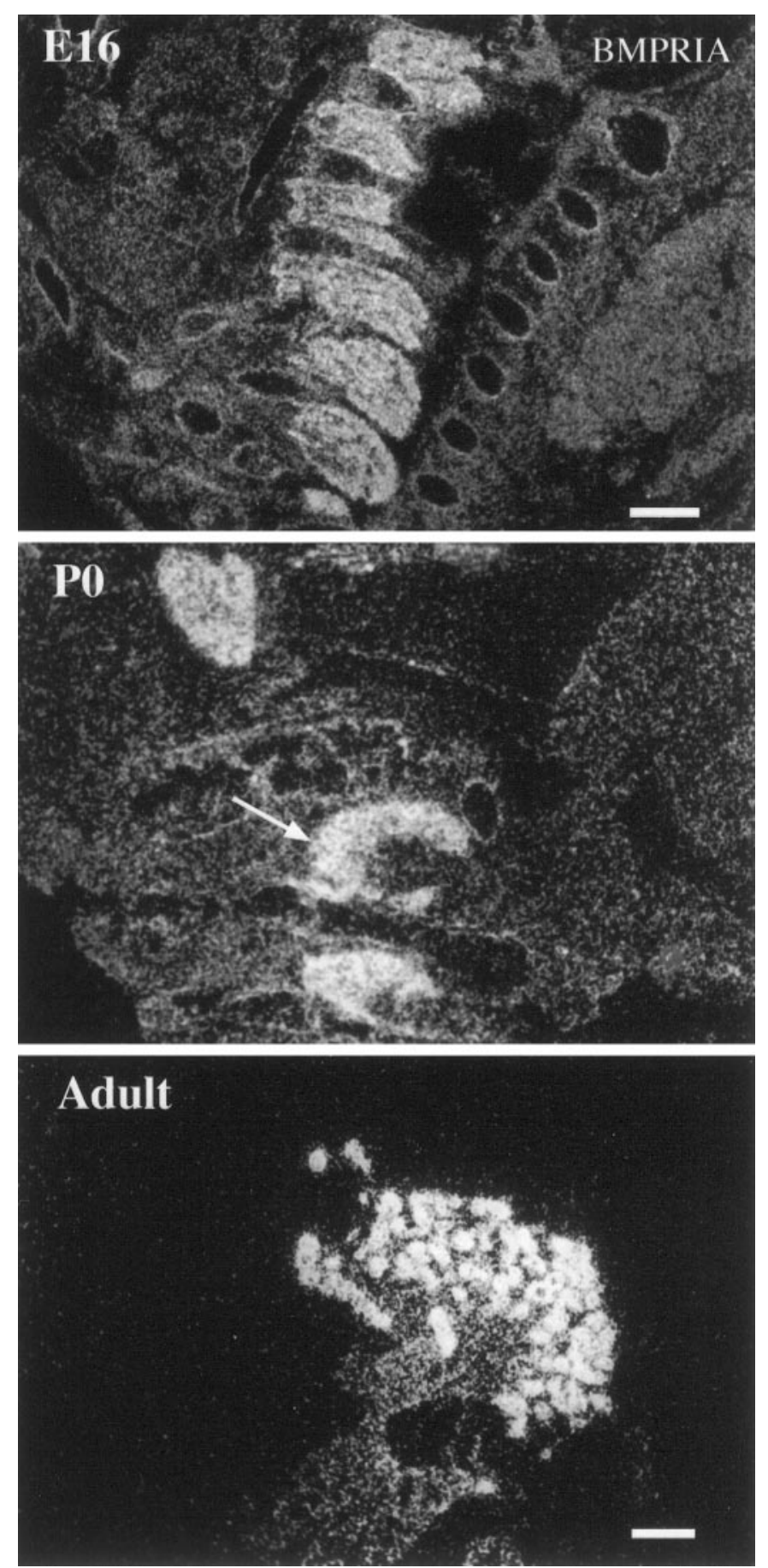

Figure 4. Expression of BMPR-IA mRNA in DRG during development. BMPR-IA mRNA is expressed homogeneously in DRG (cervical region) in the E16 mouse embryo. The abundant expression persists in P0 DRG (arrow, cervical region) and in Adult DRG (shown at higher magnification). Notice that in Adult, BMPR-IA mRNA is expressed primarily by large neuronal cells. Scale bars: E16 and PO, $300 \mu \mathrm{m} ;$ Adult, $100 \mu \mathrm{m}$.

contrast, expression is less abundant both during the neonatal period and in the adult (Figs. 7e,f, 8). Similarly, in comparison with the neonatal and adult period, the expression of BMPR-II in the cerebellar Purkinje cell layer is most apparent at P14. These experimental findings suggest that BMPR-II-mediated signaling may play an important role in the development of the cerebellum during the postnatal period.
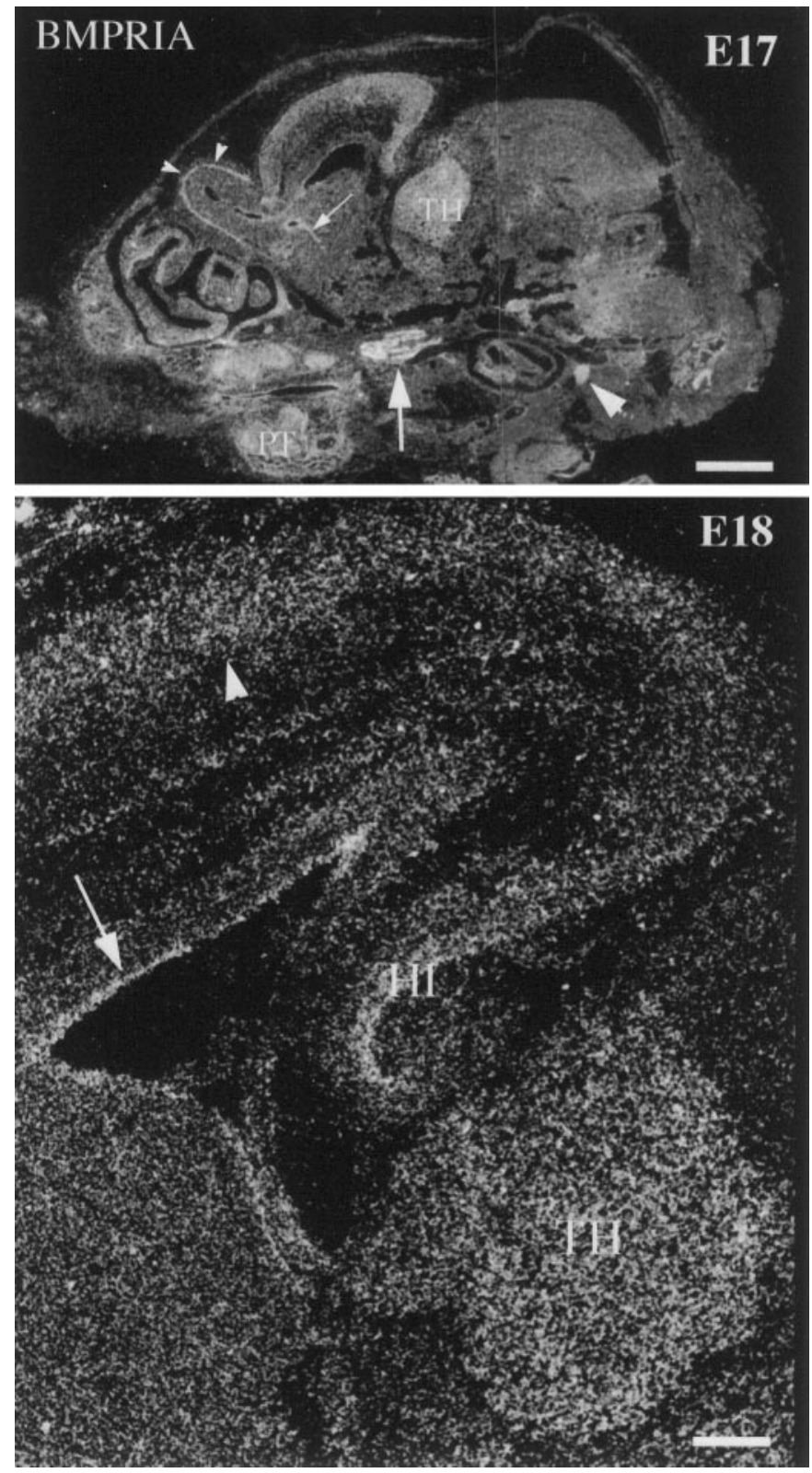

Figure 5. Expression of BMPR-IA mRNA in the E17 and E18 mouse head. BMPR-IA mRNA is expressed abundantly by the trigeminal ganglion (arrow) and nodose ganglion (arrowhead) at E17. It is also expressed homogeneously in the thalamus, mitral cell layer (small arrowheads), striatal generative zone (small arrows), cortical plate, and the primordium of the teeth. Note that in the high-power image of E18 mouse brain, BMPR-IA mRNA is expressed in the thalamus, hippocampus, VZ/SVZ (arrow), and cortical plate (arrowhead). TH, Thalamus; HI, hippocampus; $P T$, primordium of the teeth. Scale bars: $E 17,1 \mathrm{~mm} ; E 18,200 \mu \mathrm{m}$.

\section{Differential expression of BMPR-IA, BMPR-IB, and BMPR-II mRNAs in adult mouse brain}

All three BMP receptor subunit mRNAs are expressed in adult brain, but each exhibits distinct patterns of regional expression (Fig. 8). BMPR-IA mRNA is more abundant, with a broader pattern of distribution than either BMPR-IB or BMPR-II mRNA. The patterns of expression and intensity of BMPR-IA mRNA signals vary widely within specific gray matter regions. No BMPR-IA mRNA expression is detectable in white matter structures, including the corpus callosum, internal capsule, posterior or 

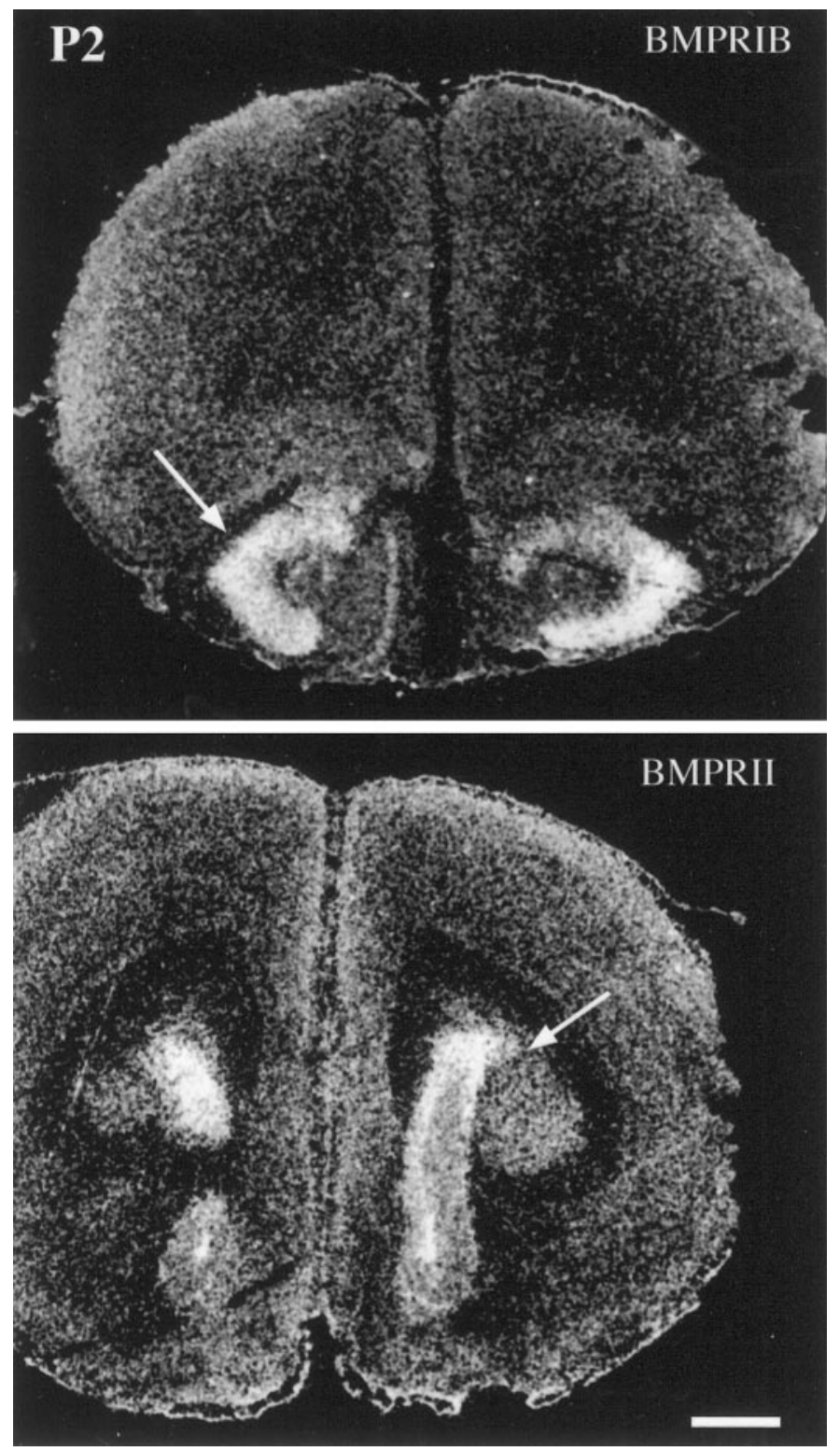

Figure 6. Expression of BMPR mRNAs within frontal cortical regions of the P2 mouse brain. BMPR-IB mRNA expression is limited to the anterior olfactory nuclei (arrow), whereas BMPR-II is expressed at high levels within the region of the SVZ (arrow). Scale bar, $500 \mu \mathrm{m}$.

anterior commissures, or in the cerebral peduncles. In the telencephalon, the expression of BMPR-IA mRNA is greatest in the mitral cell layer of the olfactory bulb (Fig. 8). In more caudal regions, hybridization is distributed across the cellular layers of the anterior olfactory nucleus, the olfactory tubercle, and the piriform cortex. In the neocortex, labeled cells are distributed across all neuronal layers, with the greatest intensity in layers IV and V (Figs. 8, 9a,b). The autoradiographic grains are primarily localized to large neuronal perikarya, but the cortical neuropil display diff use labeling that exceeds the general autoradiographic background. In the basal forebrain, weak and diffuse labeling is found in association with the caudate and putamen without clear association with specific cells or distinct cytoarchitectonic fields of these nuclei. Within hippocampus, the most intense labeling occurs in the CA regions and in the dentate gyrus (Figs. 8, 9a). In the diencephalon at the level of the dorsal thalamus, a distinct subset of nuclei are labeled by the BMPR-IA riboprobe, including the lateral dorsal, medial dorsal, paraventricular thalamic nuclei, and the zona incerta (Figs. 8, 9a). The amygdaloid nuclei and dorsal medial hypothalamic nucleus also specifically express BMPR-IA mRNA (data not shown). BMPR-IA is broadly expressed within the mesencephalon, metencephalon and myelencephalon. The highest levels of regional expression occur in the cerebellar Purkinje cell layer and within nuclei of the brainstem. In the pons, BMPR-IA mRNA is expressed at significant levels in several pontine and pontine reticular nuclei (Fig. 8). In the cerebellum, strong expression of BMPR-IA mRNA is found in the dentate, interpositus, and fastigial cerebellar nuclei (data not shown). A sharp band of hybridization clearly distinguishes the Purkinje cell layer from the surrounding granule cell and molecular layers (Fig. 8). The ependymal lining of the lateral ventricle was not labeled in the adult brain. However, it should be noted that hybridization signal is evident in the choroid plexus of the lateral ventricle (Fig. 8) and the fourth ventricle.

Although almost all transcript labeling appeared to be concentrated on large neuronal cell bodies within discrete nuclei and cortical cell layers, it is possible that astrocytes or oligodendrocytes in certain brain regions also expressed BMPR-IA mRNA. Immunohistochemistry combined with in situ hybridization was applied to address this issue using a neurofilament antibody (NF68) as a marker for neurons, CNPase as a marker for oligodendrocytes, and GFAP as a marker for astrocytes. Colocalization was detected only with the neurofilament antibody (Fig. 9c), suggesting that the expression of BMPR-IA is largely confined to neuronal subpopulations.

The expression pattern of BMPR-IB mRNA in adult brain is much more limited. The anterior olfactory nucleus is the sole regional structure that displays strong BMPR-IB transcript expression (Fig. 8). BMPR-II is expressed more abundantly with a wider pattern of distribution than BMPR-IB. Transcripts for BMPR-II are seen in the hippocampus (all regions), the choroid plexus of the lateral and IV ventricles, the cerebellar Purkinje cell layer, and the mitral cell layer of the olfactory bulb (Fig. 8). However, levels of expression of BMPR-II are of relatively lower intensity. BMPR-II expression is conspicuously absent in the areas expressing BMPR-IB, suggesting that there may be a second type II subunit associated with the BMPR-IB subunit. These distinct patterns of transcript expression indicate that the three BMP-specific receptor subunits reside in specific regional cellular subpopulations, and may thus participate in mediating distinct functional roles for individual BMPs in the normal adult brain.

\section{Induction of trkC in sympathetic ganglia by BMP-2}

The pattern of expression of BMP receptors in large DRG neurons (Fig. 4) suggested that these receptors might be associated with expression of the neurotrophin receptor trkC that is similarly distributed in DRG (Mu et al., 1993). Because previous studies have suggested that the BMPs are involved in regulating growth factor responses in neural crest derivatives (Song et al., 1998), we hypothesized that BMPs induce trkC expression. Sensory ganglia normally express trkC throughout development and also appear to preferentially express BMP receptors in neurons already expressing trkC. Therefore, the sympathetic superior cervical ganglion (SCG), a neural crest derivative that does not normally express high levels of trkC after E15 (Fagan et al., 1996) and that expresses BMP receptors relatively uniformly throughout the ganglion (see Fig. 11D), was used to test this hypothesis. 
P4

BMPRIA
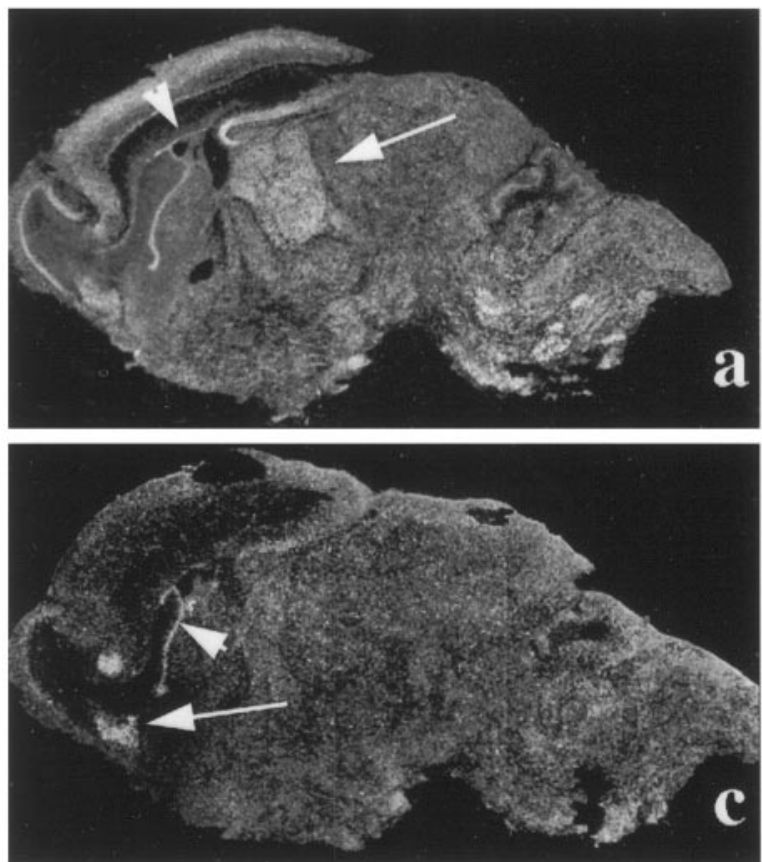

BMPRIB

\section{BMPRII}
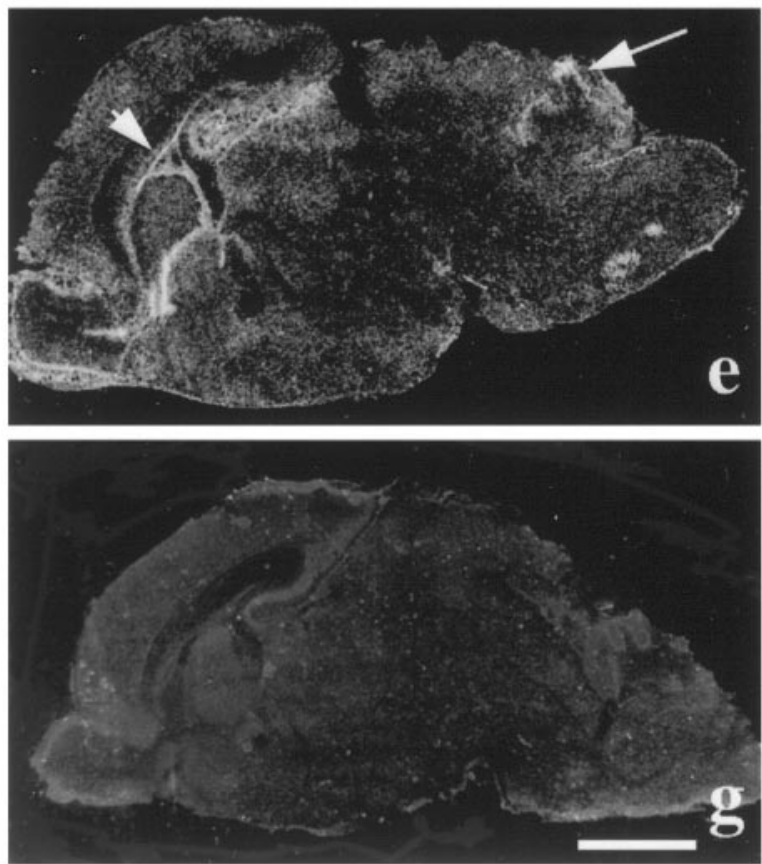

P14
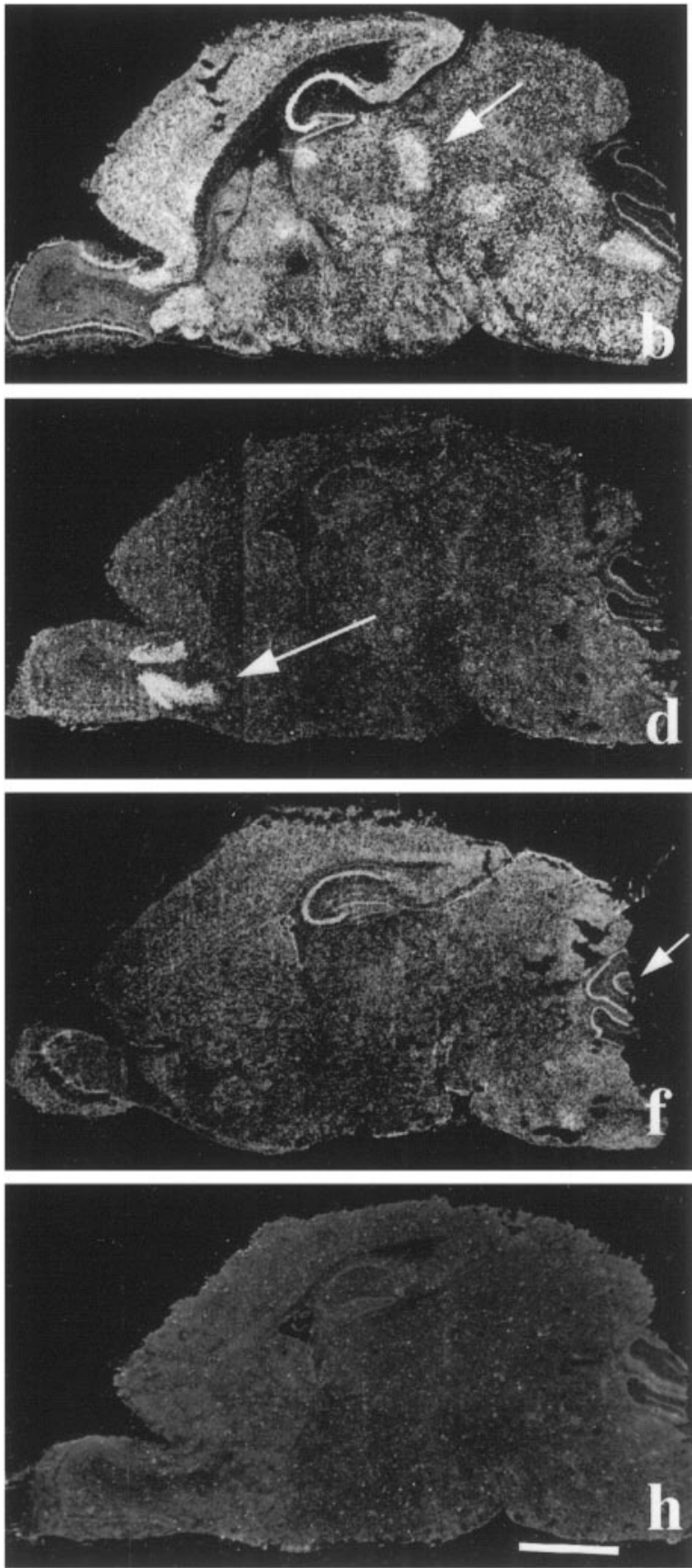

Figure 7. Expression of BMP receptor mRNAs at postnatal days 4 and 14. BMPR-IA mRNA is widely distributed in the $P 4(a)$ and $P 14(b)$ mouse brains. Notice that the expression pattern within the thalamus changes from a homogeneous pattern at $P 4$ (arrow) to expression within specific nuclei at $P 14$ (arrow). The expression of BMPR-IB is restricted to the anterior olfactory nuclei at $P 4(c)$ and $P 14(d)$. The expression of $B M P R-I I$ is seen within the hippocampus, cerebellum (arrow), and mitral cell layer of the olfactory bulb at $P 4(e)$ and $P 14(f)$. Notice that all three receptors are specifically expressed within the ependymal layer of the SVZ at $P 4(a, c, e$; arrowhead), but not at older stages, such as $P 14$ (b, $d, f$; arrowhead). BMPR-II is expressed within the cerebellum in the postnatal period at higher levels than BMPR-IA. $g, h$, Control sections hybridized with BMPR-IA sense probe showing background labeling. Scale bars: $a, c, e, g, 2 \mathrm{~mm} ; b, d, f, h, 2 \mathrm{~mm}$.

Ganglia were treated with BMP-2 and examined for levels of trkC mRNA (Fig. 10). E15 sympathetic neurons survive in culture without exogenous growth factors (Coughlin and Collins, 1985). Explants of E15 SCG were therefore cultured with no added factors or with BMP-2 and were subsequently examined for levels of trkC mRNA and actin mRNA (Fig. 10). Untreated ganglia contained minimally detectable levels of trkC. By contrast, treatment with BMP-2 increased levels of trkC mRNA $>40$-fold. The effects of BMP-2 were also examined in explants of the neonatal SCG (Fig. 10). Because sympathetic neurons at this age are dependent on NGF for survival, all neonatal cultures were treated with this factor. Ganglia treated with NGF alone contained very 

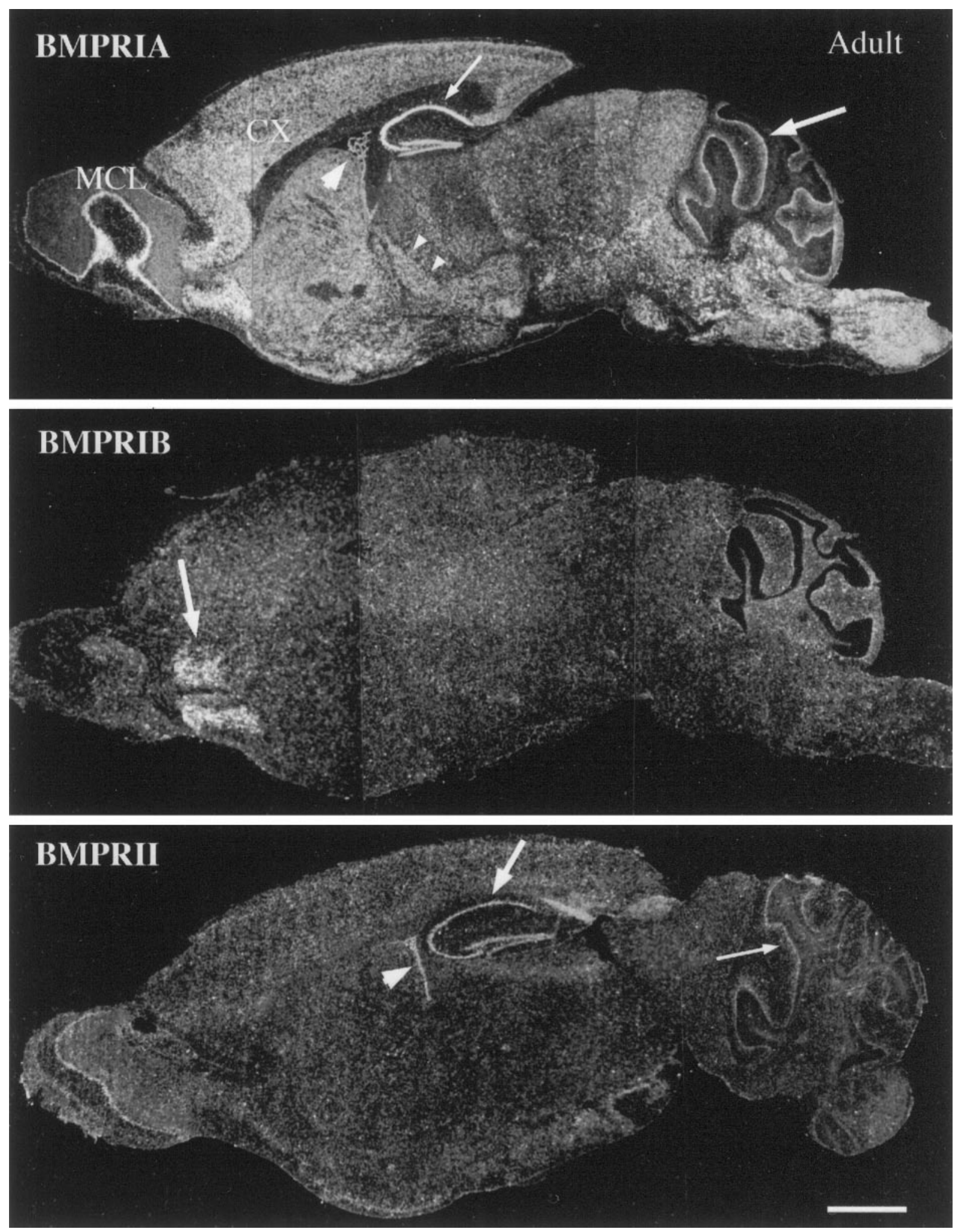

Figure 8. The expression of BMP receptor subunit mRNAs as detected by in situ hybridization and radioautography in sagittal sections of adult mouse brain. BMPR-IA mRNA is widely expressed throughout the brain. Intense labeling is seen within the cerebral cortex $(C X)$, hippocampus (small arrow), Purkinje cell layer of the cerebellum (arrow), brainstem, thalamic nuclei (small arrow heads), mitral cell layer of olfactory bulb (MCL), and choroid plexus of the lateral ventricle (arrowhead). The expression of BMPR-IB mRNA is restricted to the anterior olfactory nuclei (arrow). BMPR-II mRNA is expressed at modest levels within the hippocampus (arrow), choroid plexus (arrowhead), Purkinje cell layer of the cerebellum (small arrow), and the mitral cell layer of the olfactory bulb. Scale bar, $2 \mathrm{~mm}$. 

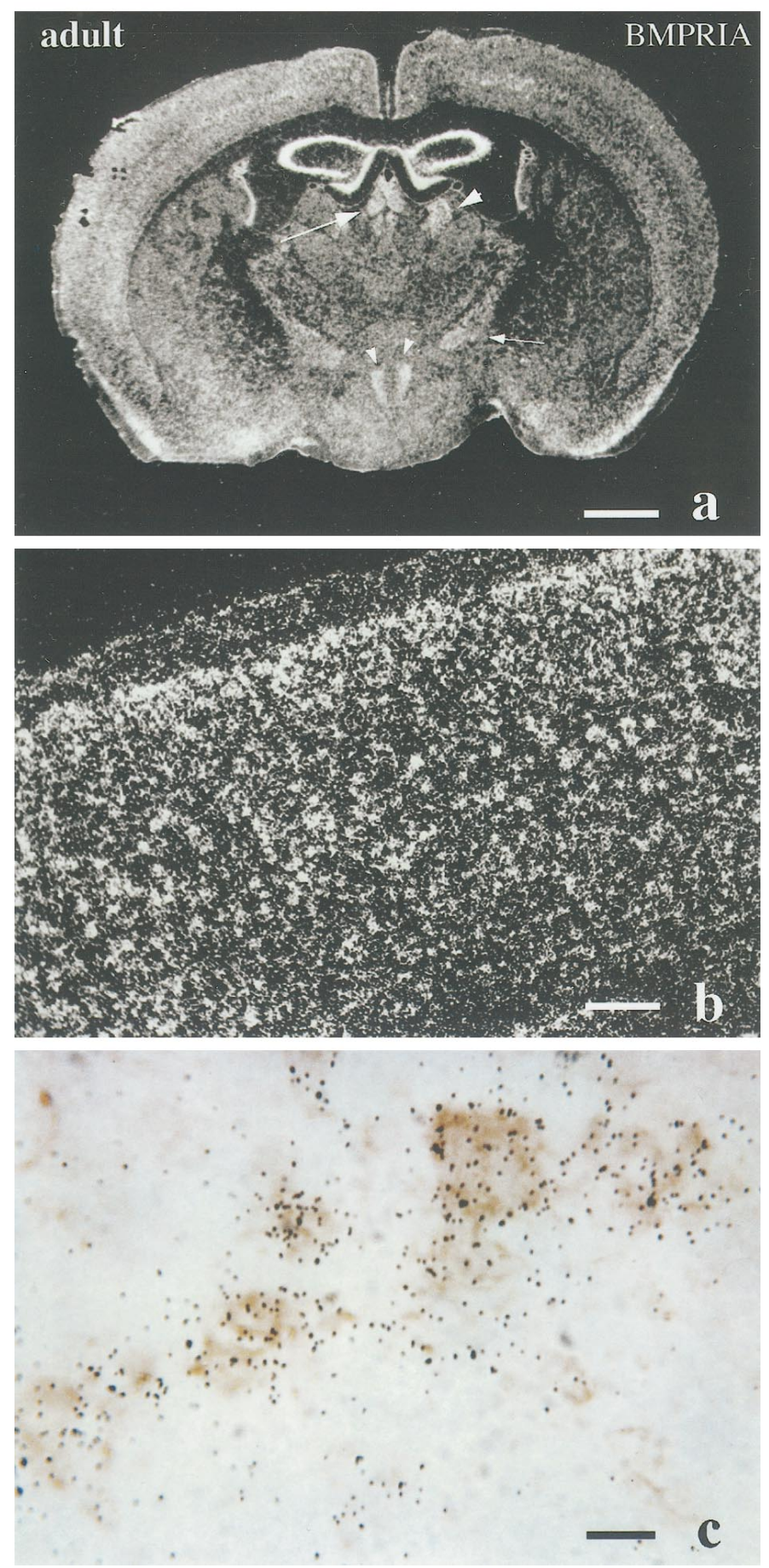

Figure 9. Expression of BMPR-IA mRNA in the adult mouse brain. $a$, Coronal section of adult brain through the region of the thalamus. Notice that BMPR-IA mRNA is expressed in medial dorsal and paraventricular thalamic nuclei (arrow), lateral dorsal nuclei (arrowhead), zona incerta (small arrows), and dorsal medial hypothalamic nucleus (small arrowhead). $b, c$, Cerebral cortical regions at high magnification. Notice in $c$ that BMPR-IA mRNA is colocalized with immunostaining for neurofilament, indicative of expression in neurons. Scale bars: $a, 1 \mathrm{~mm} ; b, 200 \mu \mathrm{m} ; c$, $100 \mu \mathrm{m}$

low levels of trkC mRNA. By comparison, treatment with BMP-2 increased levels of trkC mRNA $>25$-fold. Thus BMP-2 treatment induced expression of trkC at both developmental stages.
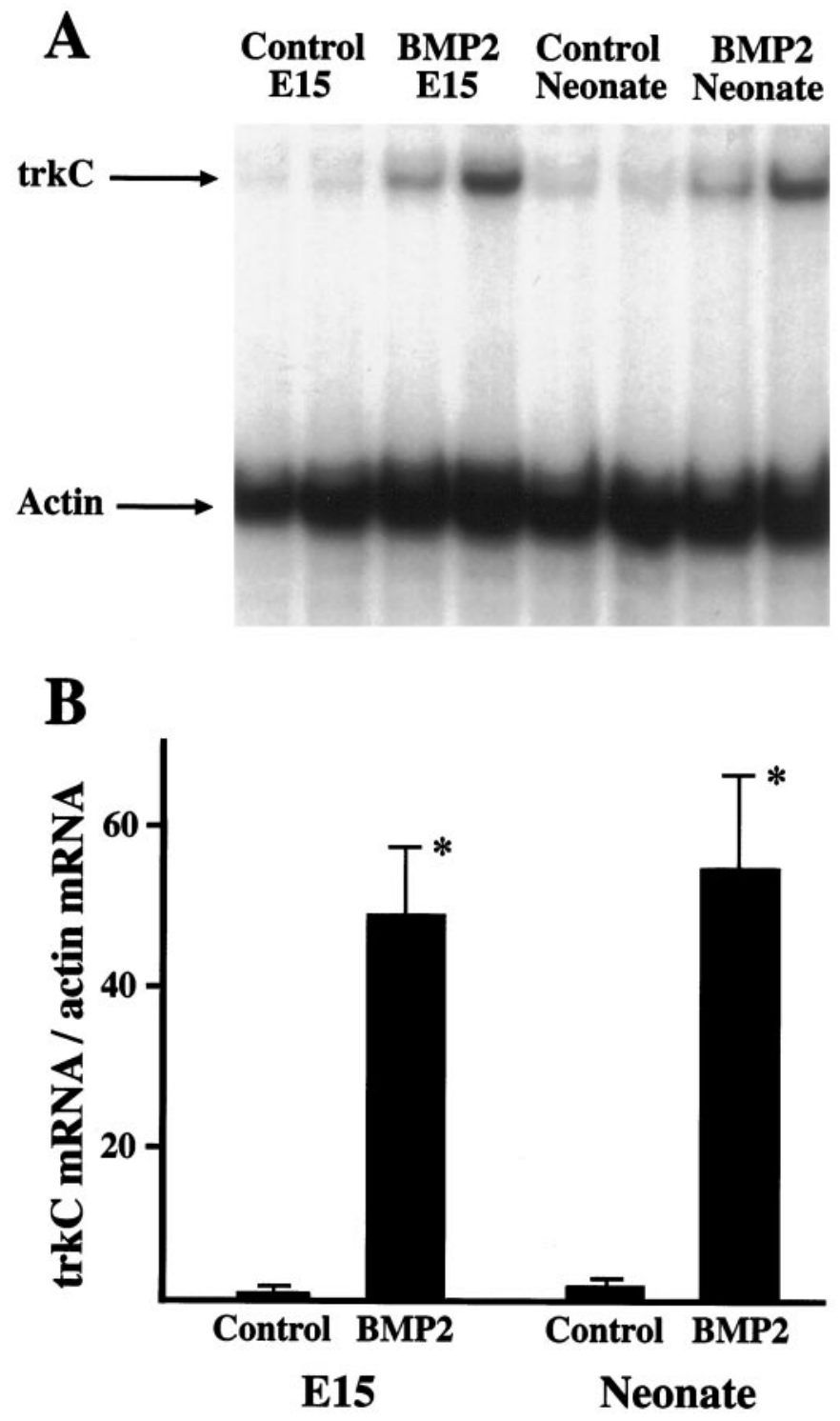

Figure 10. Regulation of trkC expression by BMP-2. A, Explants of E15 and of neonatal superior cervical ganglia were cultured in the absence or presence of BMP-2 $(10 \mathrm{ng} / \mathrm{ml})$ for $48 \mathrm{hr}$ and were examined by nuclease protection assay for levels of trkC mRNA. Levels of actin mRNA were simultaneously determined to assure equivalent loading of RNA in each lane. Note that $B M P-2$ treatment increased levels of $t r k C$ mRNA in both $E 15$ and neonatal explants. B, Levels of trkC $m R N A$ in the nuclease protection assays were quantitated densitometrically and normalized to levels of actin $m R N A$ in each sample. The level in E15 control ganglia was assigned a value of 1 , and other samples are normalized to this control value. ${ }^{*}$ Differs from respective control value at $p<0.01 ; n=4$.

Further, BMPR-1A expression persisted even in the adult SCG (Fig. 11D), suggesting ongoing responsiveness to BMP-2 throughout development.

\section{Induction of NT3 responsiveness by BMP-2}

To determine whether the induction of trkC was associated with increased NT3 responsiveness, E15 SCG explants were treated with NT3 either with or without BMP-2 cotreatment and were examined for neurite outgrowth (Fig. 11). Control (untreated) ganglia extended virtually no neurites during the first $48 \mathrm{hr}$ in culture (data not shown). Similarly, ganglia treated with BMP-2 alone (Fig. 11 $A$ ) or NT3 alone (Fig. 11B) extended few neurites. 

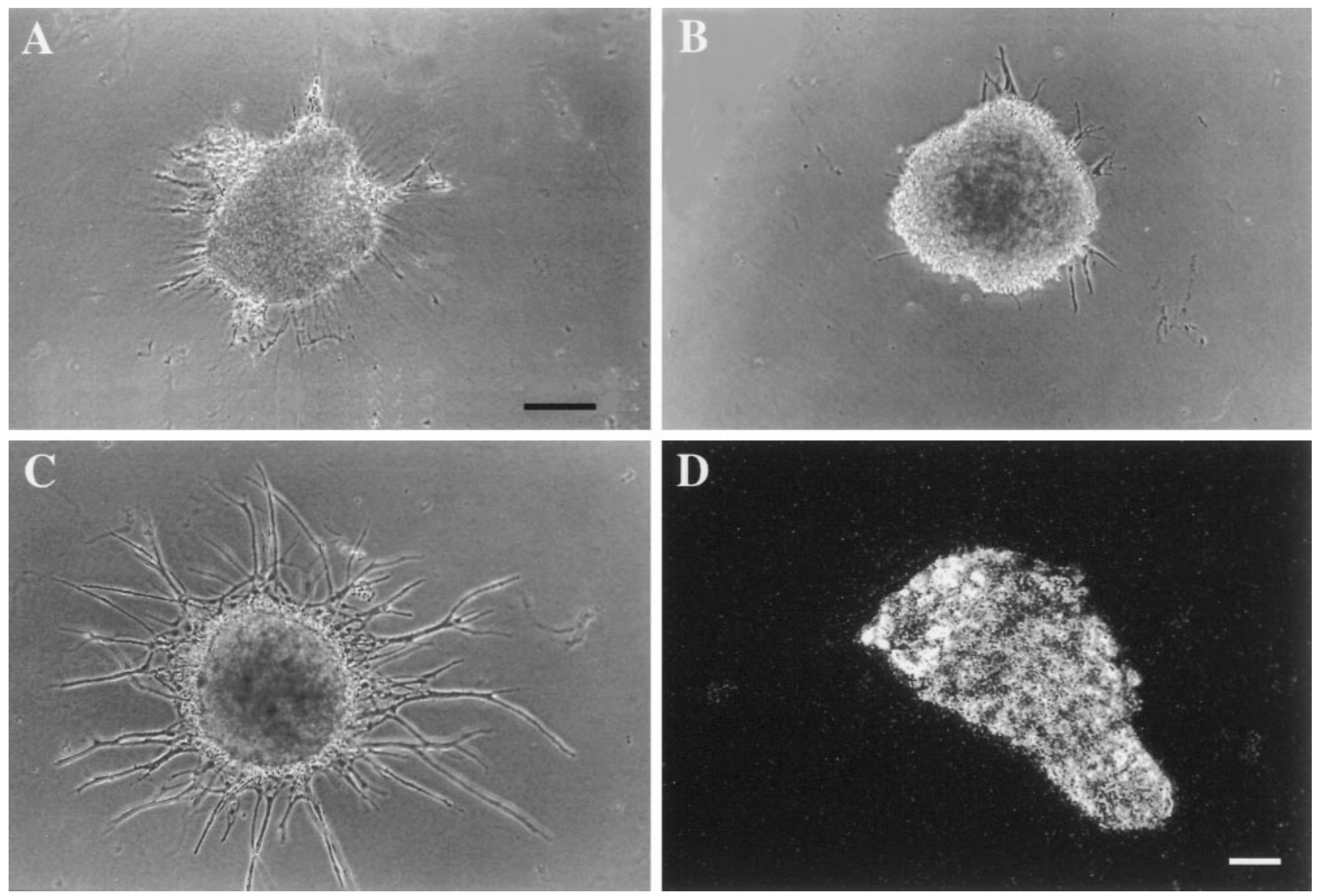

Figure 11. Effects of BMP-2 treatment on neurite extension by sympathetic ganglia. E15 sympathetic ganglia were cultured in the absence of added factors or with NT3 (20 ng/ml; $A$ ), BMP-2 $(20 \mathrm{ng} / \mathrm{ml} ; B)$, or NT3 and BMP-2 $(C)$. Like untreated ganglia (data not shown), neurite outgrowth was minimal with NT3 alone or BMP-2 alone but was much more extensive after combined treatment with NT3 and BMP-2. D, In situ hybridization analysis of an adult SCG for BMPR-1A mRNA. Note that the mRNA is still expressed abundantly even in the adult. Scale bars in $A-C, 130 \mu$ m.

However, neurite outgrowth from ganglia treated with both BMP-2 and NT3 was extensive (Fig. 11C), indicating that expression of trkC after BMP-2 treatment is associated with a gain of NT3 responsiveness.

\section{DISCUSSION}

BMP subclass ligands, which subserve multiple functions during the development of the nervous system (for review, see Mehler et al., 1997), exert their biological functions through binding to both subclass-specific (BMPRs) and subclass-selective (ActR) subunits. Therefore, localization of BMP receptors in specific regional cellular populations will help define the role of these TGF- $\beta$ subclass factors in the developing and mature nervous system.

\section{BMPs may play a role in suppression of neurogenesis and neuronal lineage commitment in the brain}

The BMPs and their receptors are expressed in very early stages of Xenopus development (Hemmati-Brivanlou and Thomsen, 1995), in which they actively suppress neurogenesis (Wilson and Hemmati-Brivanlou, 1995; Tanabe and Jessell, 1996). In the avian rhombencephalon, this early expression is associated with apoptosis of selected populations of cells, leading to segmentation (Graham et al., 1994). We found that the receptors for the BMPs are expressed within CNS neuroepithelium at E12, and expression persisted largely unchanged until E15 (Fig. 2). This period precedes gliogenesis but is temporally associated with the generation of neurons. The precise role of the BMPs at this time remains to be determined. However, a preponderance of evidence suggests that these factors suppress neurogenesis and neuronal lineage commitment in the brain (Wilson and HemmatiBrivanlou, 1995; Gross et al., 1996; Tanabe and Jessell, 1996). By contrast, the BMPs appear to induce neuronal lineage commitment of neural crest progenitor cells (Shah et al., 1996), suggesting that their actions may be population-specific.

\section{BMPs may also play an important role in the differentiation and survival of neurons within cranial ganglia and the DRG}

BMPR-IA mRNA is intensively and homogeneously expressed in the DRG from E15 to P0. By contrast, in adult DRG BMPR-IA mRNA expression is restricted to large-sized neurons located in the periphery of the ganglion. Transcripts for all three receptor subunits are expressed in nodose ganglia, and BMPR-IA and BMPR-II mRNAs are also expressed in trigeminal and sympathetic ganglia. The expression of BMP receptor subunit transcripts in cranial ganglia, DRG, and sympathetic ganglia correlates with observations that BMPs regulate the cellular maturation of neural crest-derived progenitor cells, (Graham et al., 1994; Varley et al., 1995; Reissmann et al., 1996; Shah et al., 1996; Varley and Maxwell, 1996) as well as later stages of development of certain neural crest derivatives (Fann and Patterson, 
1994; Lein et al., 1995, 1996). The precise function of the BMPs in neuronal development is unclear. BMP treatment of sympathetic progenitor cells enhances catecholaminergic expression (Varley et al., 1995; Reissmann et al., 1996; Varley and Maxwell, 1996), and treatment of more mature sympathetic neurons in culture alters their peptide neurotransmitter phenotype and fosters the outgrowth of dendrites in preference to axons (Fann and Patterson, 1994; Lein et al., 1995, 1996).

The decapentaplegic subgroup of the BMPs (BMP-2 and BMP-4), which interact with the BMP-specific receptor subunits examined in this study (Koenig et al., 1994; Mishina et al., 1995), may also participate in the induction of growth factor dependence of neural crest derivatives and may promote apoptosis in cells not exposed to other factors (Song et al., 1998). Treatment of MAH cells, an immortalized sympathoadrenal progenitor cell line (Birren and Anderson, 1990), with BMP-2 or BMP-4 induces a requirement for other growth factors to prevent apoptosis (Song et al., 1998), and BMP-4 induces apoptosis of rhombencephalic neural crest (Graham et al., 1994). In this study we found that BMP-2 treatment of sympathetic neurons increases expression of trkC and NT3 responsiveness. E15 sympathetic neurons are already responsive to NGF, and they spontaneously become dependent on neurotrophins after $48 \mathrm{hr}$ in culture even without BMP treatment. Therefore, no conclusions can be drawn regarding effects of BMP-4 in inducing neurotrophin dependence as well responsiveness to NT3. Nevertheless these observations support the thesis that the BMPs participate in the induction of growth factor responses, particularly to the neurotrophins. The early expression of BMP receptors by neurotrophin-responsive cell populations (DRG, sympathetic ganglia, cranial ganglia, and striatal neurons) is consistent with such a postulated role.

\section{Expression of all three BMP receptor subunits within the subventricular zones during the late embryonic and neonatal periods suggests that the BMPs may play diverse cellular roles, including the regulation of gliogenesis}

All three BMP receptors, BMPR-IA, BMPR-IB, and BMPR-II, are specifically expressed within the subventricular zones with maximal expression from E19 to P4, coincident with the period of cortical gliogenesis. These results support the idea that BMPs play an important role in the promotion of astroglial lineage commitment from SVZ progenitor cells (Gross et al., 1996). BMPs induce the transient expression of GFAP-immunoreactive astrocytes from cultured mouse embryonic stem cells (D'Alessandro et al., 1994). They also induce the stable elaboration of astrocytes from cultured murine SZV progenitor cells with concurrent suppression of oligodendroglial and neuronal differentiation (Gross et al., 1996). Furthermore, BMP ligands are expressed in the subventricular region and in developing brain during the late embryonic and neonatal periods (Mehler and Kessler, 1995; Soderstrom et al., 1996). These cumulative observations suggest that the BMPs may participate in the elaboration of the astrocytic lineage. It is interesting that all three BMP receptor subunits were expressed in the SVZ and that members of several different BMP subgroups promote astrocytic differentiation (Gross et al., 1996), suggesting that activation of several different BMP receptor subtypes may foster gliogenesis. Similarly, these receptors all appear to participate in the suppression of neuronal lineage commitment in the brain (Gross et al., 1996).
Widespread expression of BMPR-IA mRNA in adult brain suggests that specific BMP ligands may have important roles in regulating neural function in the adult

Transcripts for the BMPR-IA receptor subunit are broadly expressed in the adult brain. Expression appears to be restricted largely to neurons, with particularly robust patterns of expression in subpopulations within the neocortex and brainstem nuclei. These observations suggest that specific BMP ligands may exert multiple functions in the adult brain. BMPR-IA may be involved in several different signal transduction pathways that may be partially determined by different complements of receptor subunits in distinct cell types. It has been reported that BMP-2 and BMP-4 bind specifically to BMPR-IA (Koenig et al., 1994; Mishina et al., 1995). However, the distinct roles of BMP-2 and BMP-4 in adult brain have yet to be documented; homozygous null mutants for BMPR-IA, BMPR-2, and BMP-4 are embryonic lethal (Mishina et al., 1995; Winnier et al., 1995; Zhang and Bradley, 1996). Our results differ from the observations of Soderstrom et al. (1996), who reported that transcripts for BMPR-IA and BMPR-IB are not expressed in the adult brain. This discrepancy may be attributable to the type of antisense probe used for the different in situ hybridization studies. However, the nuclease protection assays and Western blot analyses (Fig. 1) leave little doubt that these receptors are actually expressed in mouse brain. Although the functions of the BMPs in the adult remain unclear, increasing evidence suggests that the BMPs promote dendritic elongation and branching (Lein et al., 1995, 1996), raising the possibility that these factors regulate dendritic growth in the mature brain.

The specific expression of BMPR-IB mRNA in anterior olfactory nuclei suggests a role for some BMP ligands in the regulation of the olfactory system

In contrast to the broad expression of BMPR-IA mRNA in brain, BMPR-IB mRNA is strikingly restricted to the anterior olfactory nucleus in the adult (Fig. 8). These results suggest that specific ligands for BMPR-IB may play an important role in the adult in regulating the function of the anterior olfactory nuclei. BMPR-IB mRNA is found in the anterior olfactory nuclei as early as E19 with continued expression throughout the postnatal period, suggesting that ligands for the receptor regulate the cellular maturation of the nuclei as well. Furthermore, at E12E16, BMPR-IB mRNA is specifically expressed in the anterior portion of the VZ, an area that may furnish progenitor cells that populate the anterior olfactory nuclei. BMPR-IB transcripts are also present at significant levels in the olfactory epithelium in E12-E19 embryos, implying that specific BMPs may be involved in the development of other aspects of the olfactory system as well.

\section{Expression of BMPR-I and BMPR-II mRNAs does not completely overlap in many adult brain regions}

BMPR-IA, BMPR-IB, and BMPR-II mRNAs do not fully overlap in the adult brain. It has been reported that BMP type I and type II receptors are both required for optimal signal transduction (Derynck, 1994; Massague, 1996; ten Dijke et al., 1996). However, the differential expression patterns of the two BMP type I receptors suggest that in adult brain, BMPR-IA and BMPR-IB may convey strikingly different physiological signals. If the current receptor model for signal transduction of BMPs is 
correct, it is likely that additional subtypes of BMPR-I and BMPR-II receptor subunits might exist. In this regard, the conspicuous absence of BMPR-II in areas of BMPR-IB expression is striking. This raises the possibility that another type II subunit may exist in brain that is coexpressed with the type IB subunit. These observations are very similar to previous findings of widespread expression of type I TGF- $\beta$ receptors in developing mouse cortex without detectable expression of TGF- $\beta$ type II receptors (Tomoda et al., 1996); this too suggested to the authors that there may be other as yet unidentified receptor components in brain. However unlike TGF- $\beta$ receptors, homodimeric BMP receptors can also transduce signals, albeit with lower efficiency than heterodimeric receptors (Hogan, 1996). It is thus also possible that lower basal levels of signaling may be sufficient in the adult brain to code for maintenance functions and/or phasic plasticity events such as dendritic branching (Lein et al., 1995). Finally, it is also possible that additional receptors within the TGF- $\beta$ superfamily may form heterodimeric signaling complexes with BMPR-IA, BMPR-IB, and BMPR-II.

\section{REFERENCES}

Arkell R, Beddington RSP (1997) BMP-7 influences pattern and growth of the developing hindbrain of mouse embryos. Development 124:1-12.

Birren SJ, Anderson DJ (1990) A V-myc-immortalized sympathoadrenal progenitor cell line in which neuronal differentiation is initiated by FGF but not NGF. Neuron 4:189-201.

Coughlin MD, Collins MB (1985) Nerve growth factor-independent development of embryonic mouse sympathetic neurons in dissociated cell culture Dev Biol 110:392-401.

D'Alessandro JS, Vetz-Aldape J, Wang EA (1994) Bone morphogenetic proteins induce differentiation in astrocyte lineage cells. Growth Factors 11:53-69.

Dale L, Howes G, Price BM, Smith JC (1992) Bone morphogenetic protein 4: a ventralizing factor in early Xenopus development. Development 115:573-585.

Derynck R (1994) TGF- $\beta$-receptor-mediated signaling. Trends Biol Sci 19:548-553.

Dewulf N, Verschueren K, Lonnoy O, Moren A, Grimsby S, Vande Spiegle K, Miyazono K, Huylebroeck D, Ten Dijke P (1995) Distinct spatial and temporal expression patterns of two type I receptors for bone morphogenetic proteins during mouse embryogenesis. Endocrinology 136:2652-2663.

Fagan AM, Zhang H, Landis S, Smeyne RJ, Silos-Santiago I, Barbacid M (1996) TrkA, but not trkC, receptors are essential for survival of sympathetic neurons in vivo. J Neurosci 16:6208-6218.

Fann MJ, Patterson PH (1994) Depolarization differentially regulates the effects of bone morphogenetic protein (BMP)-2, BMP-6 and activin A on sympathetic neuronal phenotype. J Neurochem 63:2074-2079.

Francis PH, Richardson MK, Brickell PM, Tickle C (1994) Bone morphogenetic proteins and a signaling pathway that controls patterning in the developing chick limb. Development 120:209-218.

Graham A, Francis-West P, Brickell P, Lumsden A (1994) The signaling molecule BMP4 mediates apoptosis in the rhombencephalic neural crest. Nature 372:684-686.

Graham A, Koentges G, Lumsden A (1996) Neural crest apoptosis and the establishment of craniofacial pattern: an honorable death. Mol Cell Neurosci 8:76-83.

Gross RE, Mehler MF, Mabie PC, Zang Z, Santschi L, Kessler JA (1996) Bone morphogenetic proteins promote astroglial lineage commitment by mammalian subventricular zone progenitor cells. Neuron 17:595-606.

Hemmati-Brivanlou A, Melton D (1997) Vertebrate embryonic cells will become nerve cells unless told otherwise. Cell 88:13-17.

Hemmati-Brivanlou A, Thomsen GH (1995) Ventral mesodermal patterning in Xenopus embryos: expression patterns and activities of BMP-2 and BMP-4. Dev Genet 17:78-89.

Hogan BLM (1996) Bone morphogenetic proteins: multifunctional regulators of vertebrate development. Genes Dev 10:1580-1584.

Holley SA, Neul JL, Attisano L, Wrana JL, Sasai Y, O'Connor MB, DeRobertis EM, Ferguson EL (1996) The Xenopus dorsalizing factor noggin ventralizes Drosophila embryos by preventing DPP from activating its receptor. Cell 86:607-617.
Johnson RL, Riddle RD, Tabin CJ (1994) Mechanisms of limb patterning. Curr Opin Genet Dev 4:535-542.

Kawakami Y, Ishikawa T, Shimabara M, Tanda N, Enomoto-Iwamoto M, Iwamoto M, Kuwana T, Ueki A, Noji S, Nohno T (1996) BMP signaling during bone pattern determination in the developing limb. Development 122:3557-3566.

Kessler JA, Adler J, Bohn MC, Black IB (1981) Substance P in principal sympathetic neurons: regulation by impulse activity. Science 214:335-336.

Kingsley DM (1994) The TGF- $\beta$ superfamily: new members, new receptors, and new genetic tests of function in different organisms. Genes Dev 8:133-146.

Koenig BB, Cook JS, Wolsing DH, Ting J, Tiesman JP, Correa PE, Olson CA, Pecquet AL, Ventura F, Grant RA, Chen GX, Wrana JL, Massague J, Rosenbaum JS (1994) Characterization and cloning for a receptor for BMP-2 and BMP-4 from NIH3T3 cell. Mol Cell Biol 14:5961-5974.

Liem KF, Tremml G, Roelink H, Jessell TM (1995) Dorsal differentiation of neural plate cells induced by BMP-mediated signals from epidermal ectoderm. Cell 82:969-979.

Lein P, Johnson M, Guo X, Rueger D, Higgins D (1995) Osteogenic protein-1 induces dendritic growth in rat sympathetic neurons. Neuron 15:597-605.

Lein P, Guo X, Hedges AM, Rueger D, Johnson M, Higgins D (1996) The effects of extracellular matrix and osteogenic protein-1 on the morphological differentiation of rat sympathetic neurons. Int J Dev Neurosci 14:203-215.

Liu F, Ventura F, Doody J, Massagué J (1995) Human type II receptor for bone morphogenetic proteins (BMPs): extension of the two-kinase receptor model to the BMPs. Mol Cell Biol 15:3479-3486.

Massague J (1996) TGF beta signaling receptors, transducers, and Mad proteins. Cell 85:947-950.

Mehler MF, Kessler JA (1995) Cytokines and neuronal differentiation. Crit Rev Neurobiol 9:419-446.

Mehler MF, Mabie PC, Zhang D, Kessler JA (1997) Bone morphogenetic proteins in the nervous system. Trends Neurosci 20:309-315.

Mishina Y, Suzuki A, Ueno N, Behringer RR (1995) Bmpr encodes a type I bone morphogenetic protein receptor that is essential for gastrulation during mouse embryogenesis. Genes Dev 9:3027-3037.

Mu X, Silos-Santiago I, Carroll SL, Snider WD (1993) Neurotrophin receptor genes are expressed in distinct patterns in developing dorsal root ganglia. J Neurosci 13:4029-4041.

Nohno T, Ishikawa T, Saito T, Hosokawa K, Noji S, Wosing DH, Rosenbaum JS (1995) Identification of a human type II receptor for bone morphogenetic protein-4 that forms differential heteromeric complexes with BMP type I receptors. J Biol Chem 270:22522-22526.

Piccolo S, Sasai Y, Lu B, De Robertis EM (1996) Dorsoventral patterning in Xenopus: inhibition of ventral signals by direct binding of chordin to BMP-4. Cell 86:589-598.

Reissmann E, Ernsberger U, Francis-West PH, Rueger D, Brickell PM, Rohrer H (1996) Involvement of bone morphogenetic protein-4 and bone morphogenetic protein-7 in the differentiation of the adrenergic phenotype in developing sympathetic neurons. Development 122: 2079-2088.

Rosenzweig BL, Imamura T, Okadome T, Cox GN, Yamashita H, ten Dijke P, Heldin CH, Miyazono K (1995) Cloning and characterization of a human type II receptor for bone morphogenetic proteins. Proc Natl Acad Sci USA 92:7632-7636.

Shah WM, Groves AK, Anderson DJ (1996) Alternative neural crest cell fates are instructively promoted by TGF beta superfamily members. Cell 85:331-343.

Soderstrom S, Bengtsson H, Ebendal T (1996) Expression of serine/ threonine kinase receptors including the bone morphogenetic factor type II receptor in the developing and adult rat brain. Cell Tissue Res 286:269-279.

Song Q, Mehler MF, Kessler JA (1998) Bone morphogenetic proteins induce apoptosis and growth factor dependence of cultured sympathoadrenal progenitor cells. Dev Biol, in press.

Tanabe Y, Jessell TM (1996) Diversity and pattern in the developing spinal cord. Science 274:1115-1123.

ten Dijke P, Yamashita H, Sampath TK, Reddi AH, Estevez M, Riddle DL, Ichijo H, Heldin CH, Miyazono K (1994a) Identification of type I receptors for osteogenic protein-1 and bone morphogenetic protein-4. J Biol Chem 269:16985-16988.

ten Dijke P, Yamashita H, Ichijo H, Franzen P, Laiho M, Miyazono K, 
Heldin CH (1994b) Characterization of type I receptors for transforming growth factor-beta and activin. Science 264:101-104.

ten Dijke P, Miyazomo K, Heldin CH (1996) Signaling via heterooligomeric complexes of type I and type II serine/threonine kinase receptor. Curr Opin Cell Biol 8:139-145.

Tomoda T, Shirasawa T, Yahagi YI, Ishii K, Takagi H, Furiya Y, Arai KI, Mori H, Muramatsu MA (1996) Transforming growth factor-beta is a survival factor for neonate cortical neurons: coincident expression of type I receptors in developing cerebral cortices. Dev Biol 179:79-90.

Urist MR, Mikulski A, Lietze A (1979) Solubilized and insolubilized bone morphogenetic protein. Proc Natl Acad Sci USA 76:1828-1832.

Varley, JE, Wehby, RG, Rueger, DC and Maxwell, GD (1995) Number of adrenergic and islet- 1 immunoreactive cells is increased in avian trunk neural crest cultures in the presence of human recombinant osteogenic protein-1. Dev Dyn 203:434-447.

Varley JE, Maxwell GD (1996) BMP-2 and BMP-4, but not BMP-6, increases the number of adrenergic cells which develop in quail trunk neural crest cultures. Exp Neurol 140:84-94.

Wilson PA, Hemmati-Brivanlou A (1995) Induction of epidermis and inhibition of neural fate by Bmp-4. Nature 376:331-333.

Winnier G, Blessing M, Labosky PA, Hogan BLM (1995) Bone morphogenetic protein-4 (BMP-4) is required for mesoderm formation and patterning in the mouse. Genes Dev 9:2105-2116.

Wozney JM, Rosen V, Celeste AJ, Mitsock LM, Whitters MJ, Kriz RW, Hewick RM, Wang EA (1988) Novel regulators of bone formation: molecular clones and activities. Science 242:1528-1534.

Zhang H, Bradley A (1996) Mice deficient for BMP2 are non viable and have defects in ammion/chorion and cardiac development. Development 122:2977-2986.

Zimmerman LB, Dejesus-Escobar JM, Harland RM (1996) The spemann organizer signal noggin binds and inactivates bone morphogenetic protein 4. Cell 86:599-606. 